УДК 616.831-005.1-085].001.2

DOI https://doi.org/10.11603/2312-0967.2020.4.11645

\title{
ОПИСОВЕ ПРОЄКТУВАННЯ УПРАВЛІННЯ ЯКІСТЮ МЕДИЧНОЇ ДОПОМОГИ ХВОРИМ ІЗ ГОСТРИМИ ПОРУШЕННЯМИ МОЗКОВОГО КРОВООБІГУ В ЧАСТИНІ ФАРМАКОТЕРАПIÏ
}

\section{О. Р. Левицька}

\author{
Львівський національний медичний університет імені Данила Галицького \\ levytska.oksana@gmail.com
}

ІНФОРМАЦІЯ

Надійшла до редакції / Received: 02.11 .2020

Після доопрацювання / Revised:

09.11 .2020

Прийнято до друку / Accepted: 12.11.2020

\section{Ключові слова:}

гострі порушення мозкового

кровообігу;

фрармакотерапія;

концепція управління якістю

А. Фейгенбаума;

моделювання.

\begin{abstract}
АНОТАЦІЯ
Мета роботи. Здійснити моделювання системи управління якістю медичної допомоги (МД) хворим із гострими порушеннями мозкового кровообігу (ГПМК), пов'язаною з використанням лікарських засобів (ЛЗ).

Матеріали і методи. Матеріалом дослідження були теоретичні питання управління якістю МД хворим із ГПМК у частині фрармакотерапії. Використано концепцію управління якістю А. Фейгенбаума, методи системного підходу, інформаційного пошуку, узагальнення, моделювання.

Результати й обговорення. Опрацьовано модель управління якістю МД хворим із ГПМК, реалізація якої через інтеграцію 5 управлінських рівнів та 17 вертикальних фрункцій за концепцією управління якістю А. Фейгенбаума та скеровування основних зусиль на комплексний контроль якості МД уможливить доступ хворого з ГПМК до раціональної фрармакотерапії (ФТ).

Висновки. На засадах концепції управління якістю А. Фейгенбаума опрацьована модель управління якістю МД хворим із ГПМК, реалізація якої закладами охорони здоров'я гіпотетично забезпечить отримання пацієнтами раціональної ФТ за комплексного контролю якості цього процесу, що в кінцевому результаті уможливить позитивний вплив на якість життя хворих із ГПМК.
\end{abstract}

Вступ. Гострі порушення мозкового кровообігу (ГПМК) - були та залишаються однією із найважливіших медико-соціальних проблем сучасного суспільства. В Європейському Союзі (ЄС) інсульт є другою за поширеністю причиною смерті та основною причиною інвалідності дорослих. За прогнозами експертів між 2017 та 2047 роками кількість людей, які живуть 3 інсультом, в ЄС зросте на $27 \%$, головним чином через старіння населення та покращення рівня виживання. Очікується, що між країнами зберігатимуться розбіжності, особливо у Східній Європі [1]. Ця проблема $є$ актуальною і для України, тому оптимізація якості фрармакотерапії (ФТ) хворих із ГПМК потребує серйозного управлінського вдосконалення.
Мета роботи: здійснити моделювання системи управління якістю медичної допомоги (МД) хворим із ГПМК, пов'язаною з використанням лікарських засобів (ЛЗ).

Матеріали і методи. Матеріалом дослідження були теоретичні питання управління якістю МД хворим із ГПМК у частині ФТ. Використано концепцію управління якістю А. Фейгенбаума, методи системного підходу, інформаційного пошуку, узагальнення, моделювання.

Результати й обговорення. Відповідно до доктрини Вороненка Ю. В. та співавт., що концептуальні підходи до управління якістю в медичній діяльності запозичуються зі сорери товарного виробництва [2],

ISSN 2312-0967. Pharmaceutical review. 2020. № 4 
ми опрацювали модель управління якістю МД хворим із ГПМК, пов'язаною з використанням ЛЗ, яка побудована на засадах концепції системи управління якістю А. Фейгенбаума. В її основі два положення: хворий має отримувати лише раціональну ФТ та основні зусилля потрібно скеровувати на комплексний контроль якості.

За даними рисунка, на першому рівні опрацьованої моделі відбувається підготовка до проєктування системи забезпечення якості МД хворим із ГПМК у частині ФТ, зокрема:

1. Вибір методів контролю якості МД, пов'язаноі з використанням ЛЗ. Згідно з наказом МОЗ України від 28.09.2012 р. № 752 «Про порядок контролю якості медичної допомоги» контроль якості надання МД здійснюється шляхом застосування методів зовнішнього та внутрішнього контролю якості МД, самооцінки медичних працівників, експертної оцінки, клінічного аудиту, моніторингу системи індикаторів якості, атестації/сертифрікації відповідно до вимог чинного законодавства України та законодавства Європейського Союзу [3]. 3 цих методів ми виокремили ті, які стосуються використання ЛЗ при ГПМК, а саме: внутрішній контроль якості МД, експертна оцінка результату, клінічний аудит та моніторинг системи індикаторів якості.

Суб'єктами внутрішнього контролю якості МД у закладі охорони здоров'я (3О3) виступають: наглядова рада 303, адміністрація 303 та керівники відповідних підрозділів і відділень, представник економічної служби, фрармакотерапевтична комісія (ФТК). До складу ФТК, згідно з наказом МОЗ України № 529 від 22.07.2009 р., входять: заступники керівника 303, відповідальні за надання МД, провізор клінічний (у разі його відсутності - особа з вищою медичною або фрармацевтичної освітою, на яку покладено здійснення моніторингу ефективності та безпеки ЛЗ у стаціонарі), завідувачі відділень лікувального профілю 303, завідувач організаційно-методичного (статистичного) підрозділу закладу [4]. Окремі напрямки внутрішнього контролю якості МД передбачають моніторинг дотримання стандартів у сорері охорони здоров'я, клінічних протоколів; моніторинг системи індикаторів якості МД (індикаторний аналіз); вивчення думки пацієнтів щодо наданої МД. Об'єктами внутрішнього контролю стосовно використання ЛЗ при ГПМК є медична і фрармацевтична документація, у тому числі МК стаціонарних хворих і ЛЛП.

Завданнями ФТК, які впливатимуть на якість МД, $€:$ розробка та відбір лЗ до локального фрормуляра лз 303 на основі Державного фрормуляра Лз та відповідного регіонального фрормуляра Л3; розгляд пропозицій щодо включення/виключення ЛЗ, внесення змін і доповнень до локального формуляра Л3 303; оптимізація використання ЛЗ у 303 за допомогою оцінки їх застосування, безпеки, удосконалення призначення Л3; забезпечення інформацією з питань ра- ціональної ФТ серед лікарів 303; аналіз статистичних даних щодо захворюваності, статистики госпіталізованих до стаціонару, фрармакоепідемологічний, ABC-аналіз використання Л3, визначення раціональності закупівлі ЛЗ та її відповідності пріоритетам лікування тощо [4].

Внутрішній контроль передбачає також вивчення думки пацієнтів стосовно якості отриманої ними МД чи якості свого життя та допомагає виявити очікування, які є стійкими побажаннями або запитами пацієнтів для використання зазначеної інорормації з метою планування заходів із поліпшення якості [5]. Тобто використовуються соціологічні методи контролю.

Експертний метод визначення якості може використовуватися для оцінки результатів лікування, відхилення від стандартів тощо. Згідно з наказом МО3 України від 05.02.2016 р. № 69 «Про організацію клініко-експертної оцінки якості надання медичної допомоги та медичного обслуговування» [6] експертна оцінка здійснюється, зокрема, у випадку недотримання стандартів МД та медичного обслуговування. Оскільки стандарти МД передбачають використання Л3 - їх призначення при ГПМК є об'єктом експертної оцінки. Крім того, під час експертизи перевіряються також правила зберігання Лз та виробів медичного призначення в 303.

Сучасними методами контролю якості МД є клінічний аудит та моніторинг системи індикаторів якості, що відображено в Концепції управління якістю медичної допомоги у галузі охорони здоров'я в Україні на період до 2020 р. [7]. Клінічний аудит передбачає оцінку наданої МД відповідно до критеріїв, наведених у стандартах, а якість цієї допомоги вимірюється за допомогою індикаторів якості. Він спрямований на покращання процесів та результатів допомоги пацієнтам через систематичний перегляд складових МД порівняно з визначеними критеріями та впровадження змін там, де допомога або їі результати не досягають очікуваного рівня. Складові структури, процесу та результату МД відбираються та систематично оцінюються. Необхідні зміни впроваджуються на індивідуальному, командному або інституційному рівні надання МД $[7,8]$.

2. Вибір медико-технологічних документів, які регламентують вимоги до порядку надання МД та медикаментозного лікування хворих із ГПМК. Для оцінки якості МД хворим із ГПМК необхідно обрати актуальні на момент дослідження медико-технологічні документи (адаптовані клінічні настанови, стандарти МД, уніфріковані клінічні протоколи тощо). Вони висвітлюють підходи до діагностики, лікування, реабілітації та профрілактики ГПМК на основі доказових даних ефективності тих чи інших втручань.

3. Вибір баз даних доказової медицини (ДМ) щодо ефрективності та безпеки Л3, призначених для ФТ хворих із ГПМК. Найвідомішою метабазою даних ДМ $€$ бібліотека Кокранівського співробітництва, однією

ISSN 2312-0967. Фармацевтичний часопис. 2020. № 4 


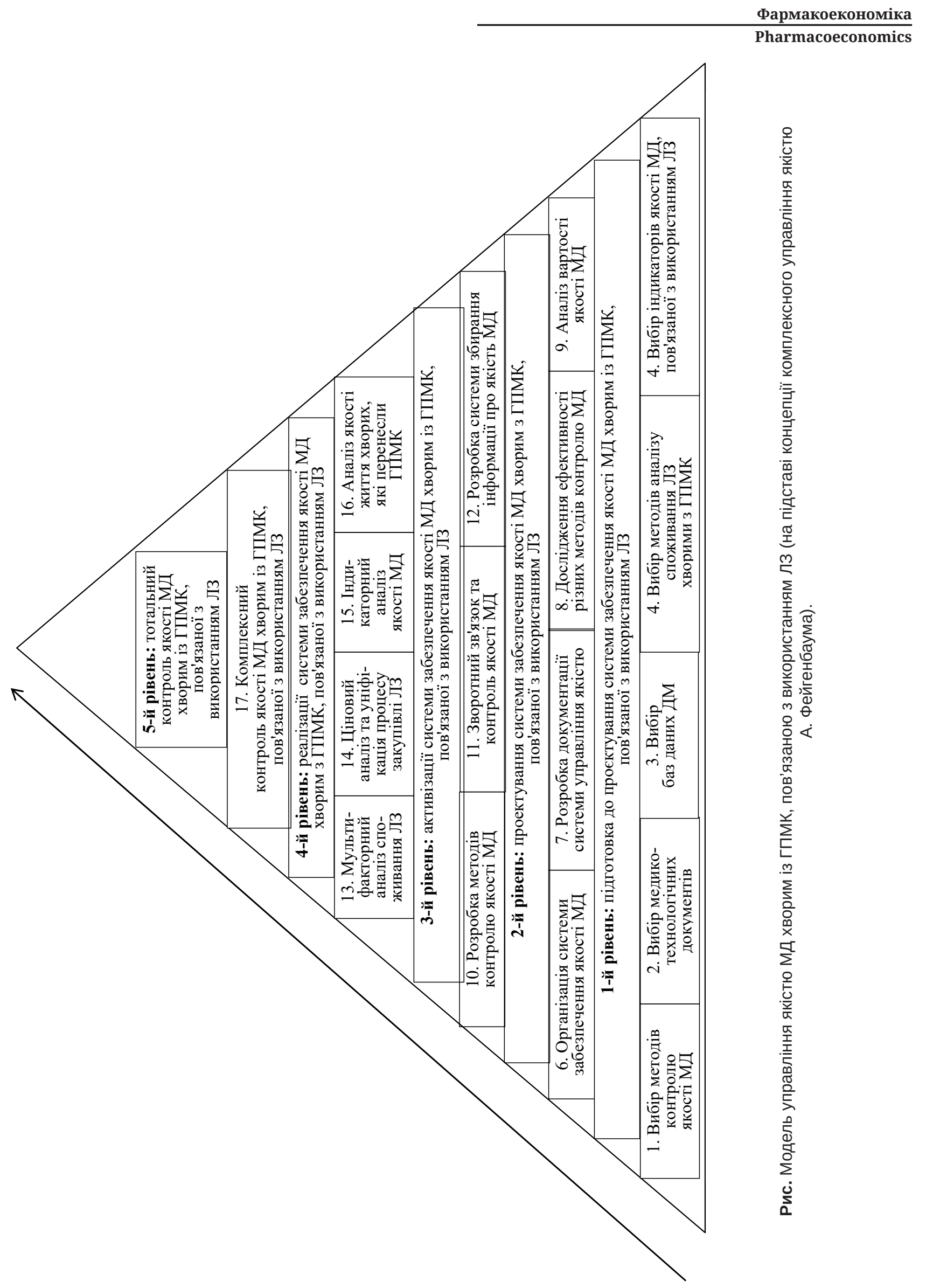

ISSN 2312-0967. Pharmaceutical review. 2020. № 4 
із складових якої $€$ Кокранівська група інсульту (Cochrane Stroke Group). Остання має базу даних досліджень в області інсульту (Database of Research in Stroke, DORIS) та джерел високих рівнів доказовості - кокранівських, систематичних оглядів, метааналізів тощо. Іншими потужними БД ДМ $€$ Medline Національної медичної бібліотеки США (US National Library of Medicine, NLM), з її електронно-пошуковою системою PubMed, а також комп'ютерний ресурс TRIP (Turning Research Into Practice - перетворення досліджень у практику). За необхідності можна скористатися іншими джерелами ДМ, перелік яких та режими доступу до них наведено на сайті МОЗ України в рубриці «Джерела доказової медицини» [https://moz. gov.ua/protokoli].

4. Вибір методів дослідження споживання ЛЗ хворими із ГПМК, економічного та фрармакоекономічного аналізів. До сучасних методів аналізу споживання ЛЗ відносять частотний (FMR), VEN (VED) -, ATC/ DDD, DU90 \% аналізи; для визначення ефективності використання коштів застосовують ABC - аналіз витрат. Фармакоекономічні методи аналізу (витрати есрективність, витрати - користь, витрати - вигода, мінімізація вартості) дають можливість розрахувати співвідношення між витратами та отриманими результатами та обрати оптимальну медичну технологію на основі показника ефективності витрат.

На сьогодні не існує універсальної методики для здійснення постійного моніторингу цін та наявності Л3. Чинні методики стосуються аналізу динаміки та варіювання оптово-відпускних, закупівельних і роздрібних цін на лз та ґрунтуються на встановленні індексів цих цін або інших показників (коефріцієнта ліквідності, адекватності платоспроможності, доступності ЛЗ тощо). Вибір тієї чи іншої методики залежить від цілей конкретного дослідження.

5. Вибір індикаторів якості МД, пов'язаної з використанням ЛЗ. У сучасних медико-технологічних документах, присвячених ГПМК, індикатори якості МД, пов'язані з використанням ЛЗ, наведено для ішемічного інсульту. Найважливішими 3 них є: проведення тромболітичної терапії; профрілактика тромбозу глибоких вен та його ускладнень; призначення антитромботичних засобів впродовж перших двох днів лікування; призначення антитромботичних засобів на момент виписування з лікарні; призначення антиагрегантів хворим із фрібриляцією передсердь на момент виписування 3 лікарні та призначення ліпідознижувальних засобів на момент виписування з лікарні. Саме їх доцільно визначати з метою оцінки якості МД.

На другому рівні відбувається проєктування системи забезпечення якості МД хворим із ГПМК, пов'язаної з використанням ЛЗ, зокрема:

6. Організація системи забезпечення якості МД. На інституційному рівні в організаційну структуру забезпечення якості МД, пов'язаної з використанням л3 в 303, входить наглядова рада та керівництво
303 (здійснює управлінський аудит). Управлінський рівень представляють керівники відповідних відділень (які входять у ФТК), представник економічної служби 303, завідувач лікарняної аптеки (за наявності такої в 303), технічний - провізор клінічний (який входить у ФТК), провізори лікарняних аптек, старша медична сестра відділення. Провізор клінічний, зокрема, забезпечує хворих висококваліфікованою МД шляхом надання рекомендацій лікарям і хворим про найбільш ефективні Л3, фрармацевтичну опіку лікарів та хворих при призначенні рецептурних ліків тощо, а також забезпечує необхідний асортимент та формування фрормуляра Л3, контакти 3 аптечними закладами для своєчасного придбання їх 303. Старша медична сестра відділення несе відповідальність за витрати Лз у відділенні, їх облік, зберігання і використання [9]. Вхідний контроль якості ЛЗ у 303 здійснюють уповноважені особи (головні/старші медичні сестри, медичні сестри; провізори або фрармацевти 303 чи лікарняних аптек), призначені наказом керівника 303 відповідальними за якість Лз [10].

7. Розробка документування системи управління якістю (перелік, зміст і структура). Документування системи управління якістю - це детальний опис системи документації, якої необхідно дотримуватися для забезпечення якості МД. Цей пункт пропонованої нами моделі передбачає, що документування системи управління якістю МД, яка пов'язана з використанням Л3, є інтегроване в документацію системи управління якості МД загалом. Вимоги до документації системи управління якістю МД встановлені в низці державних стандартів серій ISO 9000 та ISO 10000:

- ДСТУ ISO 9000:2007 «Системи управління якістю. Основні положення і словник»;

- ДСТУ ISO 9001:2009 «Системи управління якістю. Вимоги»;

- ДСТУ IWA 1:2007 «Системи управління якістю. Настанови щодо поліпшування процесів в організаціях охорони здоров'я»;

- ДСТУ ISO 9004:2012 «Управління задля досягнення сталого успіху організації. Підхід на основі управління якістю»;

- ДСТУ ISO/TR 10013:2003 «Настанови $з$ розробляння документації системи управління якістю».

Документація системи управління якістю зазвичай містить [11]: політику та цілі у сорері якості, настанову з якості, задокументовані методики, робочі інструкції (стандартні операційні процедури), програми якості, технічні умови, зовнішні документи, протоколи.

8. Дослідження ефективності різних методів контролю. Різні методи контролю (внутрішній контроль якості МД, експертна оцінка результату, клінічний аудит, моніторинг системи індикаторів якості тощо) не конкурують між собою, а взаємно доповнюють один одного.

ISSN 2312-0967. Фармацевтичний часопис. 2020. № 4 
9. Аналіз вартості якості. При аналізі вартості якості слід спиратися на дві концепції: оптимальної якості та логічної якості. Концепція оптимальної якості була розроблена експертом ВООЗ Хану В. Вуорі. Вона передбачає, що оптимальною є якість, коли користь від послуг перевищує їх вартість, що відповідає раціональному використанню ресурсів [12]. Концепція логічної якості передбачає визначення релевантності інформації та її використання у випадках, коли найпотрібніша інфрормація залишається не поміченою або ж її кількість є надмірною [13].

На третьому рівні (етапі активізації системи забезпечення якості МД хворим з ГПМК, пов'язаної з використанням Л3) відбувається:

10. Розробка технології контролю якості, зокрема узагальнення наявних та створення нових методів, які дозволять оцінити споживання ЛЗ хворими з ГПМК. Для реалізації цієї фрункції ми опрацювали методичні рекомендації «Методика аналізу цін на лікарські засоби, які закуповуються за бюджетні кошти, у порівнянні з міжнародними рекомендованими цінами» [14], науково-методичні рекомендації «Мультифакторний аналіз споживання лікарських засобів при гострих порушеннях мозкового кровообігу» [15] та «Індикатори якості медичної допомоги при ішемічному інсульті, пов'язані з використанням лікарських засобів» [16].

11. Зворотний зв'язок та контроль якості. В основу контролю якості МД покладено принцип зворотного зв'язку. Аналітична інфрормація, отримана в результаті контролю, використовується для прийняття управлінського рішення стосовно покращення якості МД, тобто реалізується зворотний зв'язок у системі управління якістю [5].

12. Розробка системи збирання інфоормації про якість. Для збирання інфрормації про якість МД оптимальними повинні стати автоматизовані технології на основі комп'ютерної техніки та спеціального програмного забезпечення - медичні інформаційні системи. Останні являють собою комплекс методологічних прийомів, технічних засобів і алгоритмів керування, призначених для збору, зберігання, обробки й передачі інформації з питань контролю якості МД на різні рівні управління [5]. Адже, як зазначено в проєкті Концепції інорорматизації охорони здоров'я, оприлюдненому в червні 2019 р., спрямованої на побудову електронної охорони здоров'я, при створенні, обміні та зберіганні даних пріоритет має електронна форма даних, що обробляється із застосуванням інформаційних комп'ютерних технологій [17]. Проте враховуючи обмеження ресурсів, сьогодні 303 можуть скористатися наявним оснащенням комп'ютерною технікою та поширеним програмним забезпеченням.

Четвертий рівень моделі характеризує етап реалізації системи забезпечення якості МД хворим із ГПМК, пов'язаної з використанням ЛЗ.
На цьому етапі за алгоритмами, наведеними у розроблених методичних рекомендаціях, відбувається проведення:

13. Мультияракторного аналізу споживання ЛЗ хворими з ГПМК (частотний (FMR), VEN (VED) -, ATC/DDD, DU90 \% аналізи; ABC - аналіз витрат), маркетингового та фрармакоекономічного аналізів (останній - за одним із методів: витрати - ефективність, витрати - користь, витрати - вигода, мінімізація вартості);

14. Цінового аналізу та уніфікації процесу закупівлі Л3, які використовуються для лікування хворих із ГПМК, зокрема шляхом порівняння 3 міжнародними рекомендованими цінами, імплементації положень законодавчих актів стосовно механізму закупівлі ЛЗ у процес закупівлі ЛЗ для потреб 303 та визначення показника доступності Л3.

15. Індикаторного аналізу якості МД хворим із ГПМК, пов'язаної з використанням ЛЗ. Крім того, може здійснюватися вивчення думки пацієнтів стосовно якості отриманої ними МД, а також проводитися

16. Аналіз якості життя хворих, які перенесли ГПМК. Такий аналіз проводиться з використанням спеціальних та загальних питальників. Використання спеціальних питальників потребує відповідної підготовки медичного фрахівця та часто - адаптації до української мови. Тому кращим може бути використання загальнодоступних питальників.

Висновки, отримані на етапі реалізації системи забезпечення якості МД хворим із ГПМК, пов'язаної 3 використанням ЛЗ, слугують підґрунтям для оптимізації управлінських рішень стосовно покращення цієї допомоги.

П'ятий рівень: тотальний (або комплексний) контроль якості включає, як зазначалося вище, лише одну складову, а саме:

17. Комплексний контроль якості МД хворим із ГПМК, пов'язаної з використанням ЛЗ. Концепція загального (комплексного) контролю якості А. Фейгенбаума передбачає, що якість необхідно впроваджувати на ранніх стадіях створення (впровадження) продукту (у нашому випадку - ЛЗ) та контролювати діяльність усіх структурних підрозділів, причетних до цього. У 303 такий контроль повинен починатися на етапі вибору клінічно та економічно доцільних ЛЗ на підставі чинних медико-технологічних документів, 3 урахуванням даних доказової медицини та аналізу реальної практики їх використання ЛЗ. Далі такий контроль повинен здійснюватися на етапі процедури закупівлі Л3 303, потім - на етапі отримання та зберігання лз у структурних підрозділах 303 згідно 3 чинними нормативними документами, а також їх використання.

Висновки. На засадах концепції управління якістю А. Фейгенбаума опрацьовано модель управління якістю МД хворим із ГПМК, реалізація якої 303 гіпотетично забезпечить отримання пацієнтами раціо-

ISSN 2312-0967. Pharmaceutical review. 2020. № 4 
нальної ФТ за комплексного контролю якості цього процесу, що в кінцевому результаті уможливить позитивний вплив на якість життя хворих із ГПМК.
Конфлікт інтересів: відсутній.

Conflicts of interest: author has no conflict of interest to declare.

\section{DESCRIPTIVE DESIGN OF QUALITY MANAGEMENT OF MEDICAL HELP FOR PATIENTS WITH ACUTE CEREBROVASCULAR ACCIDENTS IN TERMS OF PHARMACOTHERAPY}

\section{O. R. Levytska}

Danylo Halytsky Lviv National Medical University

levytska.oksana@gmail.com

The aim of the work. To carry out modeling of the quality management system of medical help $(\mathrm{MH})$ for patients with acute cerebrovascular accidents (ACVA) associated with the use of drugs.

Materials and Methods. The materials of the study were theoretical issues of quality management of MH in patients with ACVA in terms of pharmacotherapy. The concept of quality management by A. Feigenbaum, methods of system approach, information search, generalization, modeling have been used.

Results and Discussion. A model of quality management of MH for patients with ACVA has been processed, the implementation of which through the integration of 5 management levels and 17 vertical functions according to the concept of quality management by A. Feigenbaum's and directing the main efforts to complex quality control of MH will enable patients with ACVA to have access to rational pharmacotherapy (PT).

Conclusions. Based on the concept of quality management by A. Feigenbaum, a model of quality management of $\mathrm{MH}$ for patients with ACVA has been processed, the implementation of which, hypothetically, will ensure that patients receive rational PT with complex quality control of this process, which ultimately will have a positive impact on quality of life of patients with ACVA.

Key words: acute cerebrovascular accidents; pharmacotherapy; concept of quality management by A. Feigenbaum; modeling.

\section{ОПИСАТЕЛЬНОЕ ПРОЕКТИРОВАНИЕ УПРАВЛЕНИЯ КАЧЕСТВОМ МЕДИЦИНСКОЙ ПОМОЩИ БОЛЬНЫМ С ОСТРЫМИ НАРУШЕНИЯМИ МОЗГОВОГО КРОВООБРАЩЕНИЯ В ЧАСТИ ФАРМАКОТЕРАПИИ}

\section{О. Р. Левицкая}

Львовский национальный медицинский университет имени Данила Галицкого levytska.oksana@gmail.com

Цель работы. Осуществить моделирование системы управления качеством медицинской помощи (Мд) больным с острыми нарушениями мозгового кровообращения (ОНМК), связанной с использованием лекарственных средств (ЛС).

Материалы и методы. Материалом исследования были теоретические вопросы управления качеством МД больным с ОНМК в части фармакотерапии. Использована концепция управления качеством А. Фейгенбаума, методы системного подхода, инсоормационного поиска, обобщения, моделирования.

Результаты и обсуждение. Разработана модель управления качеством МД больным с ОНМК, реализация которой через интеграцию 5 управленческих уровней и 17 вертикальных фрункций согласно концепции управления качеством А. Фейгенбаума и направление основных усилий на комплексный контроль качества МД сделает возможным доступ больного с ОНМК к рациональной фармакотерапии (ФТ).

Выводы. На основе концепции управления качеством А. Фейгенбаума разработана модель управления качеством МД больным с ОНМК, реализация которой учреждениями здравоохранения гипотетически обеспечит получение пациентами рациональной ФТ при комплексном контроле качества этого процесса, что в конечном итоге сделает возможным положительное влияние на качество жизни больных с ОНМК.

Ключевые слова: острые нарушения мозгового кровообращения; фрармакотерапия; концепция управления качеством А. Фейгенбаума; моделирование. 


\section{Список бібліографрічних посилань}

1. Burden of stroke in Europe. Thirty-year projections of incidence, prevalence, deaths, and disability-adjusted life years . H. A. Wafa, Ch. D. A. Wolfe, E. Emmett et al. Stroke. 2020. Vol. 51, Is. 8. P. 2418-2427. URL : https://www.ahajournals.org/doi/10.1161/ STROKEAHA.120.029606.

2. Вороненко Ю. В., Горачук В. В., Криштопа Б. П. Історичні етапи менеджменту якості: досвід для сучасної системи охорони здоров'я. Україна. Здоров'я нації. 2012. № 2 (22). С. 70-73.

3. Про порядок контролю якості медичної допомоги: наказ МОЗ України від 28.09.2012 р. № 752 URL: https://zakon.rada.gov.ua/laws/show/z1996-12\#Text

4. Положення про фрармакотерапевтичну комісію закладу охорони здоров'я: наказ МОЗ України від 22.07.2009 p. № 529 URL: https://zakon.rada.gov.ua/ rada/show/z1009-09 (зі змінами, внесеними згідно з наказом MO3 України від 26.06.2014р. № 429). URL: https://zakon.rada.gov.ua/laws/show/z0824-14\#Text

5. Організація контролю якості медичної допомоги в закладах охорони здоров'я (методичні рекомендації) / укл. : Ю. В. Вороненко та ін. К., 2014. 31 с.

6. Про організацію клініко-експертної оцінки якості надання медичної допомоги та медичного обслуговування : наказ МОЗ України від 05.02.2016 p. № 69 URL: https://zakon.rada.gov.ua/ laws/main/z0286-16

7. Про затвердження Концепції управління якістю медичної допомоги у галузі охорони здоров'я в Україні на період до 2020 р. : наказ МОЗ України від 01.08.2011 p. № 454. URL: http://www.moz.gov.ua/ ua/portal/dn_20110801_454.html.

8. Методика розробки системи індикаторів якості медичної допомоги : наказ МО3 України від 28.09.2012 p. № 751. URL: http://zakon.rada.gov.ua/ laws/show/z2002-12.

9. Довідник кваліфрікаційних характеристик профресій працівників. Випуск 78. Охорона здоров'я : наказ

\section{References}

1. Wafa HA, Wolfe ChDA, Emmett E, Roth GA, Johnson CO, Wang Y. Burden of stroke in Europe. Thirtyyear projections of incidence, prevalence, deaths, and disability-adjusted life years. Stroke. 2020;51(8): 2418-27. Available from: https://www.ahajournals.org/ doi/10.1161/STROKEAHA.120.029606 [Accessed August 2020].

2. Voronenko YuV, Gorachuk VV, Kryshtopa BP. [Historical stages of quality management: experience to modern health care]. Ukraina. Zdorovia natsii. 2012;2 (22): 70-3. Ukrainian.

3. Order of the Minisrty of Health of Ukraine "On the procedure for quality control of medical care" from August 28, 2012, No 752. [Electronic resource]. Available from: https://zakon.rada.gov.ua/laws/show/z1996-12\#Text [Accessed August 2020]. Ukrainian.

4. Order of the Minisrty of Health of Ukraine "Regulations
МО3 України від 29.03.2002 р. № 117 (зі змінами). URL: https://zakon.rada.gov.ua/rada/show/va11728202.

10. Про внесення змін до Правил зберігання та проведення контролю якості лікарських засобів у лікувально-профрілактичних закладах : наказ МО3 України від 03.04.2018 р. № 610. URL: https://zakon. rada.gov.ua/laws/main/z0522-18

11. Настанови 3 розробляння документації системи управління якістю: ДСТУ ISO/TR 10013:2003. К. : Держспоживстандарт України, 2004. 15 с.

12. Vuori H. V. Quality assurance of health services: concepts and methodology. Copenhagen: Regional Office for Europe, World Health Organization. 1982. 127 p.

13. Степаненко А. Контроль якості медичної допомоги в Україні - голий король? Ваше здоров'я, 2017. URL: http://www.vz.kiev.ua/kontrol-yakosti-medychnoyidopomogy-v-ukrayini-golyj-korol/.

14. Методика аналізу цін на лікарські засоби, які закуповуються за бюджетні кошти, у порівнянні 3 міжнародними рекомендованими цінами (методичні рекомендації) / укл. Б. П. Громовик, О. Р. Левицька. K., 2012. 20 c.

15. Левицька О. Р., Громовик Б. П. Мультифракторний аналіз споживання лікарських засобів при гострих порушеннях мозкового кровообігу (науковометодичні рекомендації). Львів : ЛНМУ імені Данила Галицького, 2017. 40 с.

16. Левицька О. Р., Громовик Б. П., Яворська Н. П. Індикатори якості медичної допомоги при ішемічному інсульті, пов'язані з використанням лікарських засобів (науково-методичні рекомендації). Львів : Ліга-Прес, 2019. 35 с.

17. Концепція інформатизації охорони здоров'я України. URL: http://vikisoft.kiev.ua/\%d0\%bd\%d0\%be\%d0\%b 2\%d0\%b8\%d0\%bd\%d0\%b8/\%d0\%ba\%d0\%be\%d0\% bd\%d1\%86\%d0\%b5\%d0\%bf\%d1\%86\%d1\%96\%d1\% $8 f-$

on the pharmacotherapeutic commission of the health care institution" from June 26, 2014, No 529. [Electronic resource]. Available from: https://zakon.rada.gov. ua/laws/show/z0824-14\#Text [Accessed August 2020]. Ukrainian.

5. Voronenko YuV, Goida NG, Decyk OZ, Zimenkovsky AB, Kryshtopa BP. et al. Guidelines: "Organization of quality control of medical care in health care facilities" [Методичні рекомендації "Організація контролю якості медичної допомоги в закладах охорони здоров'я"]. Kyiv: 2014; Ukrainian.

6. Order of the Ministry of Health of Ukraine "On the organization of clinical and expert assessment of the quality of medical care and medical care" from February 05, 2016, No 69. [Electronic resource]. Available from: https://zakon.rada.gov.ua/laws/main/z0286-16 [Accessed August 2020]. Ukrainian.

ISSN 2312-0967. Pharmaceutical review. 2020. № 4 
7. Order of the Ministry of Health of Ukraine " On approval of the Concept of quality management of medical care in the field of health care in Ukraine for the period up to $2020 "$ from August 01, 2011, No 454. [Electronic resource]. Available from: http://www.moz.gov.ua/ua/portal/dn_20110801_454.html [Accessed August 2020]. Ukrainian.

8. Order of the Ministry of Health of Ukraine "Methods of developing a system of indicators of quality of medical care" from September 28, 2012, No 751. [Electronic resource]. Available from: http://zakon.rada.gov.ua/laws/ show/z2002-12 [Accessed August 2020]. Ukrainian.

9. Order of the Ministry of Health of Ukraine "Handbook of qualification characteristics of employees' professions. Issue 78. Health care" from March 29, 2002, No 117. [Electronic resource]. Available from: https://zakon. rada.gov.ua/rada/show/va117282-02. [Accessed August 2020]. Ukrainian.

10. Order of the Ministry of Health of Ukraine "On amendments to the Rules of storage and quality control of medicines in medical and preventive institutions" from April 03, 2018, No 610. [Electronic resource]. Available from: https://zakon.rada.gov.ua/laws/main/z0522-18 [Accessed August 2020]. Ukrainian.

11. Guidelines for the development of quality management system documentation: DSTU ISO/TR 10013. Kyiv; 2003. Ukrainian Derzhspozhyvstandart, 2004. Ukrainian.

12. Vuori HV. Quality assurance of health services: concepts and methodology. Copenhagen: Regional Office for Europe, World Health Organization; 1982.

13. Stepanenko A. Quality control of medical care in
Ukraine - a naked king? Your health, 2017. [Electronic resource]. Available from: http://www.vz.kiev.ua/kontrol-yakosti-medychnoyi-dopomogy-v-ukrayini-golyjkorol/ [Accessed August 2020]. Ukrainian.

14. Hromovyk BP, Levytska OR. Guidelines: "Methods of analysis of prices for medicines purchased for budget funds, in comparison with international recommended prices". [Методичні рекомендації "Методика аналізу цін на лікарські засоби, які закупляються за бюджетні кошти, у порівнянні 3 міжнародними рекомендованими цінами"] Kyiv; 2012. Ukrainian.

15. Levytska OR, Hromovyk BP. Scientific and methodical recommendations "Multifactorial analysis of the consumption of drugs in acute disorders of cerebral circulation". [Науково-методичні рекомендації "Мультифракторний аналіз споживання лікарських засобів при гострих порушеннях мозкового кровообігу"] Lviv. Danylo Halytsky Lviv National Medical University; 2017. Ukrainian.

16. Levytska OR, Hromovyk BP, Yavorska NP. Scientific and methodical recommendations "Indicators of quality of medical care at an ischemic stroke connected with use of medicines. [Науково-методичні рекомендації "Індикатори якості медичної допомоги при ішемічному інсульті, пов'язані з використанням лікарських засобів"] Lviv: Liha-Pres; 2019. Ukrainian.

17. The concept of health care informatization in Ukraine. [Electronic resource]. Available from: http://vikisoft. kiev.ua/\%d0\%bd\%d0\%be\%d0\%b2\%d0\%b8\%d0\%bd $\%$ d0\%b8/\%d0\%ba\%d0\%be\%d0\%bd\%d1\%86\%d0\% b5\%d0\%bf\%d1\%86\%d1\%96\%d1\%8f- [Accessed August 2020]. Ukrainian.

\section{Відомості про автора}

Левицька О. Р. - канд. фрармац., наук, доцент кафедри організації та економіки фрармації, Львівський національний медичний університет імені Данила Галицького, Львів, Україна. E-mail: levytska.oksana@gmail.com, ORCID 00000002-8113-2587.

\section{Information about the author}

Levytska O. R. - PhD (Pharmacy), Associate Professor of the Department of Organization and Economics of Pharmacy, Danylo Halytsky Lviv National Medical University, Lviv, Ukraine. E-mail: levytska.oksana@gmail.com, ORCID 0000-00028113-2587. 